\title{
Hubungan antara Tingkat Pendidikan Ibu dan Kecerdasan Logika-Matematika Siswa R.A. Muslimat N.U. Ponorogo
}

\author{
Kurnia Hidayati \\ STAIN Ponorogo \\ E-mail: nina_khdn@yahoo.co.id
}

\begin{abstract}
This study describes the relationship between mother's education level and students' logic-mathematical intelligence at the RA NU 074 Ronowijayan Ponorogo. This study was conducted with a quantitative approach through the study of documentation and questionnaires. The data is processed by the formula percentages and standard deviations and analyzed by correlation of contingency coefficients. The results showed that (1) The level of maternal education were high for as many as 10 people or $50 \%$, the categories are as many as 7 people or $35 \%$ and the low category as many as 3 people or 15\%; (2) Logicalmathematical intelligence which include high category with a score of 62.103 as many as three people, the medium category with a score of 44.697 to 62.103 as many as 13 people and low category with a score of 44.697 of 4 people and (3) There is a positive and significant relationship between mother's education level and logic-mathematical intelligence RA NU's 074 students Ronowijayan Ponorogo at a significance level of $5 \%$ with $\Phi \sigma$ table or 0.60006060 .444 then $\mathrm{HO}$ is rejected and Ha accepted.
\end{abstract}

Keywords: level of mother education, intelligence of logic-mathematics

\begin{abstract}
Abstrak
Penelitian ini menjelaskan hubungan antara tingkat pendidikan ibu dan kecerdasan logika-matematika pada siswa RA Muslimat NU 074 Ronowijayan Ponorogo. Kajian ini dilaksanakan dengan pendekatan kuantitatif melalui studi dokumentasi dan angket. Datanya diolah dengan rumus persentase dan standar deviasi serta dianalisis dengan Korelasi Koefisien Kontingensi. Hasil penelitian menunjukkan bahwa (1) Tingkat pendidikan ibu yang termasuk kategori tinggi sebanyak 10 orang atau $50 \%$, kategori sedang sebanyak 7 orang atau $35 \%$ dan kategori rendah sebanyak 3 orang atau 15\%; (2) Kecerdasan logika-matematika yang termasuk kategori tinggi dengan skor ${ }^{-} 62,103$ sebanyak 3 orang, kategori sedang dengan skor 44,697 - 62,103 sebanyak 13 orang dan kategori rendah dengan skor 44,697 sebanyak 4 orang dan (3) Terdapat hubungan yang positif dan signifikan antara tingkat pendidikan ibu dan kecerdasan logika-matematika siswa RA Muslimat NU 074 Ronowijayan Ponorogo pada taraf signifikansi 5\% dengan $\Phi \sigma$ tabel atau 0.60006060 .444 maka $\mathrm{H}_{0}$ ditolak dan $\mathrm{H}_{\mathrm{a}}$ diterima.
\end{abstract}

Kata kunci: tingkat pendidikan ibu, kecerdasan logika-matematika 


\section{A. Pendahuluan}

Pada dasarnya, setiap anak dilahirkan cerdas dengan membawa potensi dan keunikan masing-masing, yang memungkinkan mereka untuk menjadi cerdas. Tugas orang tua dan pendidik ialah mempertahankan sifat-sifat yang menjadi dasar kecerdasan anak agar bertahan sampai tumbuh dewasa. Dengan memberikan stimulasi yang baik untuk merangsang dan mengoptimalkan fungsi otak dan kecerdasan anak.

Anak dengan kemampuan logika-matematika akan senang dengan rumus dan pola-pola abstrak. Ciri anak yang memiliki kecenderungan kecerdasan logika-matematika adalah anak gemar yang bereksplorasi untuk memenuhi rasa ingin tahunya, seperti menjelajah setiap sudut, mengamati benda-benda yang unik, hobi mengutak-atik benda serta melakukan uji coba. Kecerdasan logika-matematika pada anak dapat dirangsang sejak usia dini. Orang tua dapat mengenalkan konsep matematika sejak usia dini, dari lingkungan sekitar dan pengalaman sehari-hari anak serta memberikan stimulasi yang mendukung.

Dalam lingkup wahana keluarga inti (yang terdiri dari ayah, ibu dan anak), keduanya memiliki kedudukan yang sama, yaitu sebagai orang tua. Namun, peran ibu sebagai lambang kasih sayang membuat anak lebih dekat kepada ibu, dari pada ayah yang berperan sebagai sumber kekuasaan dan hakim. ${ }^{1}$ Selain itu, ibu juga sebagai lingkungan pertama tempat anak bersosialisasi dari lahir hingga dewasa. Begitu pula, anak lebih banyak menghabiskan waktunya bersama ibu dari pada ayah ataupun orang lain. Hal ini yang membuat kedekatan ibu \& anak melebihi kedekatan siapapun.

Setiap orang membutuhkan ilmu sebagai bekal hidupnya. Salah satunya didapat dengan bersosialisasi dengan lingkungan keluarga. Dengan ilmu yang dimiliki oleh ibu, dan kebiasaan imitatif sang anak. Seakan ibu memberi wacana dalam berperilaku, budi pekerti dan adat kebiasaan sehari-hari yang baik dalam kehidupan anak. Sehingga mampu membentuk pribadi yang terbina, terdidik dan belajar dari pengalaman langsung, yang akan berpengaruh pada kegiatan anak sebagai siswa di sekolah.

Pendidikan anak usia dini pada jalur pendidikan formal berbentuk Taman Kanak-kanak, Roudhotul Athfal atau bentuk lain

1 Abdullah Idi \& Safarina H. D., Sosiologi Pendidikan Individu, Masyarakat dan Pendidikan (Jakarta: Rajawali, 2011), hlm. 9 - 11. 
yang sederajat. ${ }^{2}$ Usia dini merupakan usia emas (golden age) pertumbuhan dan perkembangan pada berbagai aspek psiko-fisik yang menjadi peletak dasar bagi perkembangan selanjutnya. Pada masa ini, jaringan otak manusia mengalami peningkatan yang sangat pesat. Oleh sebab itu, pendidikan usia dini merupakan dasar bagi perkembangan masa selanjutnya dan merupakan tahap pembinaan awal menuju terbinanya sumber daya manusia Indonesia yang berkualitas. Proses perkembangan otak manusia sepanjang rentang kehidupan yaitu:

1. Usia $0-4$ tahun perkembangan otak mencapai $50 \%$

2. Usia $5-8$ tahun perkembangan otak mencapai $80 \%$

3. Usia 8-12 tahun perkembangan otak mencapai $90 \%$

4. Usia $12-18$ tahun perkembangan otak mencapai $100 \%{ }^{3}$

Berdasarkan fakta tersebut, maka perkembangan jaringan otak manusia sekitar $80 \%$ terjadi pada masa usia dini. Sehingga diperlukan layanan pendidikan yang sesuai agar mereka dapat tumbuh dan berkembang secara optimal. Selain itu, dapat juga dilakukan upaya pendidikan yang meliputi program stimulasi, bimbingan pengasuhan dan kegiatan pembelajaran untuk mengembangkan berbagai potensi yang dimiliki anak, yang diimplementasikan melalui pengembangan kurikulum.

Di sisi lain, pendidikan anak usia dini memandang anak sebagai individu yang utuh, sehingga memberikan pelayanan menyeluruh, meliputi berbagai aspek perkembangan fisik dan psikis. Secara kodrati, sebenarnya anak sejak lahir memiliki lebih dari satu bakat. Akan tetapi, bakat tersebut bersifat potensial. Untuk itu, anak perlu diberikan pendidikan yang sesuai dengan perkembangannya. Pertumbuhan dan perkembangan anak akan tercapai secara optimal, apabila diciptakan situasi dan keadaan yang kondusif sesuai dengan kebutuhan anak yang berbeda satu dengan lainnya. Sehingga layanan pendidikan yang diberikan harus Memperhatikan keberagaman budaya, agama, kondisi alam dan pola kehidupan sehari-hari anak.

${ }^{2}$ Undang-Undang Republik Indonesia Nomor 20 Tahun 2003 tentang Sistem Pendidikan Nasional, Pasal 28 Ayat 3.

3 Tim Guru RA Muslimat NU 074 Ronowijayan Siman Ponorogo, Kurikulum Tingkat Satuan Pendidikan (KTSP) RA Muslimat NU 074 Ronowijayan Siman Ponorogo Tahun Pelajaran 2012/2013 (Ponorogo: 2012), hlm. 1. 
Di dalam RA Muslimat NU 074 Ronowijayan Ponorogo, semua siswa belajar bersama dengan fasilitas yang sama, yang diberikan oleh pihak sekolah. Para guru memberikan bimbingan dan perhatian yang sama kepada seluruh siswa tanpa melihat perbedaan latar belakang mereka. Setelah melalui proses belajar yang sama, tidak semua siswa memperoleh hasil yang sama pula. Hal ini disebabkan oleh perbedaan tingkat pendidikan orang tua mereka, terutama ibu.

\section{B. Rumusan Masalah}

1. Bagaimana tingkat pendidikan ibu siswa RA Muslimat NU 074 Ronowijayan Ponorogo?

2. Bagaimana kecerdasan logika-matematika siswa RA Muslimat NU 074 Ronowijayan Ponorogo?

3. Adakah hubungan antara tingkat pendidikan ibu dan kecerdasan logika-matematika pada siswa RA Muslimat NU 074 Ronowijayan Ponorogo?

\section{Hakikat Tingkat Pendidikan Ibu}

Tingkat dalam Kamus Besar Bahasa Indonesia diartikan sebagai susunan yang berlapis-lapis, tumpuan pada tangga (jenjang); tinggi rendah martabat (kedudukan, jabatan, kemajuan, peradaban dan sebagainya), pangkat, derajat, taraf, kelas; batas waktu (masa), sepadan suatu peristiwa (proses, kejadian dan sebagainya); babak ataupun tahap. ${ }^{4}$ Tingkat diartikan sebagai babak, fase, stadium, tahap dan taraf. ${ }^{5}$ Dalam penelitian ini, tingkat diartikan sebagai jenjang atau tahap.

Dalam Kamus Besar Bahasa Indonesia, pendidikan diartikan sebagai proses pengubahan cara berpikir atau tata laku seseorang maupun sekelompok orang dalam usaha mendewasakan manusia melalui upaya pengajaran dan latihan, proses perbuatan serta cara mendidik. ${ }^{6}$ Sedangkan menurut Undang-Undang Sistem Pendidikan Nasional (Sisdiknas), pendidikan adalah usaha sadar dan terencana untuk mewujudkan suasana belajar dan proses

4 Tim Penyusun Kamus Pusat Bahasa Edisi 3, Kamus Besar Bahasa Indonesia (Jakarta: Balai Pustaka, 2005), hlm. 1197.

5 Eko Endarmoko, Tesaurus Bahasa Indonesia (Jakarta: Gramedia Pustaka Utama, 2009), hlm. 672.

${ }^{6}$ Tim Penyusun Kamus Pusat Bahasa Edisi 3, Kamus Besar ..., hlm. 263. 
pembelajaran agar peserta didik secara aktif mengembangkan potensi dirinya agar memiliki kekuatan spiritual keagamaan, pengendalian diri, kepribadian, kecerdasan, akhlak mulia, serta keterampilan yang diperlukan dirinya, masyarakat, bangsa dan negara. ${ }^{7}$

Jalur pendidikan terdiri atas pendidikan formal, non formal dan informal yang dapat saling melengkapi dan memperkaya. ${ }^{8}$ Jenjang pendidikan formal terdiri atas pendidikan dasar, pendidikan menengah dan pendidikan tinggi. ${ }^{9}$ Pendidikan dasar merupakan jenjang pendidikan yang melandasi jenjang pendidikan menengah. Pendidikan dasar berbentuk Sekolah Dasar (SD) dan Madrasah Ibtidaiyah (MI) atau bentuk lain yang sederajat, serta Sekolah Menengah Pertama (SMP) dan Madrasah Tsanawiyah (MTs) atau bentuk lain yang sederajat. ${ }^{10}$

Pendidikan menengah merupakan lanjutan pendidikan dasar. Pendidikan menengah terdiri atas pendidikan menengah umum dan pendidikan menengah kejuruan. Pendidikan menengah berbentuk Sekolah Menengah Atas (SMA), Madrasah Aliyah (MA), Sekolah Menengah Kejuruan (SMK) dan Madrasah Aliyah Kejuruan (MAK) serta bentuk lain yang sederajat. ${ }^{11}$

Pendidikan tinggi merupakan jenjang pendidikan setelah pendidikan menengah yang mencakup program pendidikan diploma, sarjana, magister, spesialis dan doktor yang diselenggarakan oleh perguruan tinggi. ${ }^{12}$ Perguruan tinggi dapat berbentuk akademi, politeknik, sekolah tinggi, institut atau universitas. ${ }^{13}$

Dalam penelitian ini yang dimaksud dengan tingkat pendidikan ibu adalah pendidikan formal yang paling terakhir dijalani oleh ibu, baik pada pendidikan dasar, menengah maupun tinggi. Sehingga bahasan berikut menarik untuk ditelaah, sejauh mana korelasi antara tingkat pendidikan ibu dan kecerdasan logika-matematika seorang siswa.

\footnotetext{
${ }^{7}$ UU Sisdiknas Pasal 1 Ayat (1).

${ }^{8}$ UU Sisdiknas Pasal 13 Ayat (1).

${ }^{9}$ UU Sisdiknas Pasal Pasal 14.

${ }^{10}$ UU Sisdiknas Pasal 17 Ayat $(1-2)$.

${ }^{11}$ UU Sisdiknas Pasal 18 Ayat $(1-3)$.

${ }^{12}$ UU Sisdiknas Pasal 19 Ayat (1).

${ }^{13}$ UU Sisdiknas Pasal 20 Ayat (1).
} 


\section{Kecerdasan Logika-Matematika bagi Siswa RA}

Kecerdasan logika-matematika terkadang disebut dengan istilah kecerdasan matematis-logis, kecerdasan logika atau matematik, keahlian matematis atau kecerdasan logis-matematis. Di antara sekian banyak istilah tersebut terdapat beberapa pengertian mengenai kecerdasan logika matematika, yaitu:

a. Kecerdasan matematis-logis, yaitu kemampuan menggunakan angka dengan baik dan melakukan penalaran yang benar. ${ }^{14}$

b. Kecerdasan logika atau matematik sering disebut berpikir ilmiah, termasuk berpikir deduktif dan induktif. Kecerdasan ini diaktifkan bila seseorang menghadapi masalah atau tantangan baru dan berusaha menyelesaikannya. ${ }^{15}$

c. Keahlian matematis, yaitu kemampuan mengerjakan operasioperasi matematika: ${ }^{16}$

d. Kecerdasan logis-matematis, yaitu kecerdasan yang digunakan untuk menyelesaikan persoalan matematika. ${ }^{17}$

Kecerdasan logika-matematika adalah kecerdasan yang melibatkan keterampilan mengolah angka dengan baik dan atau kemahiran menggunakan penalaran atau logika dengan benar. Kecerdasan ini meliputi kepekaan pada hubungan logis, sebab akibat, dan logika-logika lainnya. Proses yang digunakan dalam kecerdasan matematis-logis ini antara lain klasifikasi (penggolongan atau pengelompokan), pengambilan kesimpulan dan perhitungan.

Howard Gardner seperti dikutip Robert J. Stenberg mengusulkan sebuah teori yang dinamakan teori multiintelegensi. ${ }^{18}$ Teori ini menyatakan bahwa inteligensi mengandung berbagai konstruk yang independen satu sama lain. Jadi, bukan hanya dibentuk oleh satu konstruk tunggal saja. ${ }^{19}$ Pada teori multi-

14 Saifullah, Mencerdaskan Anak: Mengoptimalkan Kecerdasan Intelektual, Emosi dan Spiritual Anak (Jombang: Lintas Media, 2004), hlm. 30 .

15 C. Asri. Budiningsih, Belajar dan Pembelajaran (Jakarta: Rineka Cipta, 2005), hlm. 114.

${ }^{16}$ Santrock, Perkembangan Anak Jilid 1...., hlm. 323.

17 Robert J. Stenberg. Psikologi Kognitif, terj. Yudi Santoso, (Yogyakarta: Pustaka Pelajar, 2008), hlm. 473.

${ }_{18}$ Multi inteligensi (Multiple Intelligences) terkadang disebut dengan istilah kecerdasan jamak atau kecerdasan ganda.

19 Robert J. Stenberg. Psikologi Kognitif ,terj. Yudi Santoso, (Yogyakarta: Pustaka Pelajar, 2008), hlm. 472. 
inteligensi terdapat tujuh bidang kecerdasan, masing-masing merupakan sistem pemfungsian yang terpisah-pisah. Meski, sistem ini dapat berinteraksi untuk menghasilkan performa cerdas. Ketujuh macam kecerdasan tersebut adalah: (1) kecerdasan musik, (2) kecerdasan gerakan badan, (3) kecerdasan logika-matematika, (4) kecerdasan linguistik, (5) kecerdasan ruang, (6) kecerdasan antar pribadi, dan (7) kecerdasan pribadi. ${ }^{20}$ Dalam buku terakhirnya, Intelligence Reframed, Gardner menambahkan tiga kecerdasan lain, yaitu: (1) kecerdasan naturalis, (2) kecerdasan eksistensial, dan (3) kecerdasan spiritual. ${ }^{21}$

Menurut Gardner seperti dikutip John W. Santrock, setiap orang memiliki semua tipe kecerdasan tersebut, tetapi dalam tingkatan yang bervariasi. ${ }^{22}$ Akibatnya, kita cenderung memproses informasi dengan cara yang berlainan. Kita mampu belajar dengan baik ketika dapat mengaplikasikan keunggulan kecerdasan tersebut yang kita miliki. Pada umumnya, satu kecerdasan lebih menonjol dari pada kecerdasan yang lain, tetapi di dalam diri manusia tersedia kemampuan untuk mengaktifkan semua kecerdasan tersebut. Kecerdasan tersebut dapat ditingkatkan dengan cara mengetahui faktor-faktor yang mempengaruhi kemampuan intelektual, yaitu: (1) keturunan, (2) latar belakang sosial ekonomi, (3) lingkungan hidup, (4) kondisi fisik dan (5) iklim emosi. ${ }^{23}$

Beberapa kecerdasan yang terkait dengan kecerdasan logikamatematika antara lain: membilang (mengurutkan angka dari kecil ke besar misalnya dari 1-20), mengenal konsep matematika secara sederhana seperti konsep penjumlahan dan pengurangan, mengenal konsep logika matematika sederhana misalnya lebih besar, lebih kecil, sedikit, banyak, jauh, dekat, panjang, pendek, dan lain-lain.

Menurut Linda \& Bruce Campbell seperti dikutip Hamzah B. Uno \& Masri Kuadrat, bahwa kecerdasan logis matematika biasanya dikaitkan dengan otak yang melibatkan beberapa

${ }^{20}$ Howard Gardner, (Multiple Intelligences) Teori dalam Praktek, terj. Alexander Sindoro, (Batam: Interaksara, 2003), hlm. 36 - 46.

${ }^{21}$ Agus Efendi, Revolusi Kecerdasan Abad 21: Kritik MI, EI, SQ, AQ \& Successful Intelligence atas IQ (Bandung: Alfabeta, 2005), hlm. 136.

22 John W. Santrock, Perkembangan Anak Jilid 1, terj. Mila Rachmawati \& Anna Kuswanti, (Jakarta: Erlangga, 2007), hlm. 323.

${ }^{23}$ Slameto, Belajar dan Faktor-faktor yang Mempengaruhinya (Jakarta: Rineka Cipta, 2003), hlm. 131. 
komponen, yaitu: perhitungan secara matematis, berpikir logis, pemecahan masalah, pertimbangan induktif, pertimbangan deduktif dan ketajaman pola-pola serta hubungan-hubungan. ${ }^{24}$ Seoarang siswa yang memiliki kecerdasan logka-matematika tinggi cenderung menyenangi dan menyukai kegiatan menganalisis dan mempelajari sebab akibat terjadinya sesuatu, karena ia menyenangi berpikir.

Hal tersebut sesuai dengan pernyataan Musrofi, yang menyebutkan bahwa karakteristik orang yang memiliki kecerdasan logika-matematika adalah: suka memecahkan masalah puzzle, bermain dengan angka, suka menghitung, ingin tahu bagaimana sesuatu bekerja, disiplin terhadap jadwal, sesuai peraturan, suka kalimat atau mengatakan "Jika ... maka ....", suka mengumpulkan dan membuat klasifikasi terhadap sesuatu, memecahkan masalah secara analitik baik dalam matematika, logika, pemecahan masalah tetapi harus ada alasan terhadap kejadian sesuatu. $^{25}$

Howard Gardner seperti dikutip oleh Suharsono mengemukakan terdapat hal-hal penting yang perlu dilakukan untuk mengembangkan kecerdasan matematika, yaitu: (1) merasakan fungsi dan tujuan matematis dalam lingkungannya, (2) mengenal konsep-konsep yang bersifat kuantitatif atau angkaangka, (3) menggunakan simbol untuk menentukan obyek, (4) menunjukkan keterampilan pemecahan masalah, (5) menggunakan keterampilan estimating, perhitungan algoritma dan menggambarkan informasi visual dalam bentuk grafik, (6) menyukai komputer, penelitian, fisika dan sebagainya, dan (7) mengungkapkan ketertarikan dalam karier. ${ }^{26}$

Sehingga dalam penelitian ini, menyatakan bahwa kecerdasan logika-matematika adalah kecerdasan yang berkaitan dengan berhitung atau menggunakan angka dalam kehidupan sehari-hari, berpikir logis, linier dan teratur. Hal tersebut dapat dilihat pada Pencapaian Kompetensi Kecerdasan Logika-Matematika pada

${ }^{24}$ Hamzah B. Uno \& Masri Kuadrat, Mengelola Kecerdasan dalam Pembelajaran: Sebuah Konsep Pembelajaran Berbasis Kecerdasan (Jakarta: Bumi Aksara, 2009), hlm. 117.

${ }^{25}$ M. Musrofi. Melesatkan Prestasi Akademik Siswa: Cara Praktis Meningkatkan Prestasi Akademik Siswa Tanpa Kekerasan dan Tanpa Harus Menambah Jam Belajar (Yogyakarta: Pedagogia, 2010), hlm. 127-128.

${ }^{26}$ Suharsono, Melejitkan IQ, IE \& IS (Depok: Inisiasi Press, 2004), hlm. 91. 
Buku Laporan Perkembangan Siswa RA Muslimat NU 074 Ronowijayan Ponorogo.

Siswa RA atau biasa dikenal dengan Taman Kanak-kanak berada pada kisaran usia 4 hingga 7 tahun. Dalam periode perkembangan anak-anak pada usia ini berada pada tahapan pikiran pra-operasional. Pada usia ini, anak belajar berpikir menggunakan simbol-simbol dan pencitraan batiniah. Namun, pikiran mereka masih tidak sistematis dan tidak logis. Pikiran di titik tersebut sangat berbeda dengan pikiran orang dewasa.

Menurut Piaget, kegiatan yang dapat dilakukan pada usia ini adalah kegiatan yang dapat dikatakan sebagai tindakan-tindakan kognitif, seperti mengklasifikasikan sekelompok obyek (classifying), menata letak benda menurut urutan tertentu (seriation) dan membilang (counting). Pada tahap berikut, pemikiran anak lebih banyak berdasarkan pada pengalaman kongkrit dari pada pemikiran logis. Sehingga jika ia melihat obyek-obyek yang nampak berbeda, maka ia akan mengatakan berbeda pula. ${ }^{27}$

Anak-anak pada usia ini biasanya memiliki karakteristik sebagai berikut:

a. Aspek perkembangan fisik. Pada usia ini anak-anak membuat kemajuan besar dalam keterampilan motorik kasar, seperti berlari dan melompat yang melibatkan penggunaan otot besar. $^{28}$

b. Aspek Kognitif. Pada usia ini anak-anak dapat menggunakan simbol, memahami identitas, memahami sebab akibat, mampu mengklasifikasi, memahami angka dan memiliki empati. $^{29}$

c. Aspek Psiko-sosial. Pada usia ini anak-anak mulai memahami emosi diri sendiri, lebih menyukai bermain dengan teman yang berjenis kelamin sama dan hubungan terhadap saudara kandung bersifat positif. ${ }^{30}$

${ }^{27}$ William Crain, Teori Perkembangan: Konsep dan Aplikasi, terj. Yudi Santoso, (Yogyakarta: Pustaka Pelajar, 2007), hlm. 171.

28 Diane E. Papalia et. al, Human Development (Psikologi Perkembangan) Edisi Kesembilan, terj. A. K. Anwar, (Jakarta: Kencana Prenada Media Group, 2008), hlm. 315.

${ }^{29}$ Papalia et. al, Human Development ..., hlm. 324.

${ }^{30}$ Papalia et. al, Human Development ..., hlm. 415 - 418. 
Berdasar teori tersebut, hipotesis yang diajukan untuk penelitian ini adalah:

$\mathrm{H}_{\mathrm{o}}$ : Tidak terdapat hubungan antara tingkat pendidikan ibu dan kecerdasan logika-matematika pada siswa RA Muslimat NU 074 Ponorogo.

$\mathrm{H}_{\mathrm{a}}$ : Terdapat hubungan antara tingkat pendidikan ibu dan kecerdasan logika-matematika pada siswa RA Muslimat NU 074 Ponorogo.

\section{E. Metode Penelitian}

Penelitian ini dilakukan dengan menggunakan rancangan penelitian kuantitatif. Penelitian kuantitatif didasari oleh filsafat positivisme yang menekankan fenomena-fenomena obyektif dan dikaji secara kuantitatif. ${ }^{31}$ Penelitian kuantitatif digunakan untuk meneliti pada populasi atau sampel tertentu, teknik pengambilan sampel pada umumnya dilakukan secara random, pengumpulan data menggunakan instrumen penelitian, analisis data bersifat kuantitatif atau statistik dengan tujuan untuk menguji hipotesis yang telah ditetapkan. ${ }^{32}$

Penelitian ini dilaksanakan di RA Muslimat NU 074 Ronowijayan, Jalan Pramuka Gang III No. 2 Kelurahan Ronowijayan Kecamatan Siman Kabupaten Ponorogo. Penelitian ini dilaksanakan selama dua bulan, mulai bulan Juli sampai dengan Oktober 2013.

Populasi adalah wilayah generalisasi yang terdiri atas obyek/subyek yang mempunyai kualitas dan karakteristik tertentu, dan telah ditetapkan oleh peneliti untuk dipelajari dan kemudian ditarik kesimpulannya. ${ }^{33}$ Populasi pada penelitian ini adalah siswa RA Muslimat NU 074 Ronowijayan Ponorogo kelas B sebanyak 20 siswa.

Sampel adalah sebagian atau wakil populasi yang diteliti. ${ }^{34}$ Teknik pengambilan sampel adalah cara yang digunakan untuk menentukan jumlah sampel dalam penelitian. Dalam penelitian ini teknik pengambilan sampel dilakukan dengan sampling jenuh.

31 Nana Syaodih Sukmadinata, Metode Penelitian Pendidikan (Bandung: Remaja Rosdakarya, 2007), hlm. 53.

${ }^{32}$ Sugiyono, Metode Penelitian Pendidikan ..., hlm. 14. hlm. 61 .

33 Sugiyono, Statistika untuk Penelitian (Bandung: Alfabeta, 2009),

${ }^{34}$ Suharsimi Arikunto, Prosedur Penelitian: Suatu Pendekatan Praktek (Jakarta: Rineka Cipta, 2006), hlm. 119. 
Sampling jenuh adalah teknik penentuan sampel bila semua anggota populasi digunakan sebagai sampel. Hal ini sering dilakukan bila jumlah populasi relatif kecil, kurang dari 30 orang, atau penelitian yang ingin membuat generalisasi dengan kesalahan yang sangat kecil. ${ }^{35}$ Dari siswa RA Muslimat NU 074 Ronowijayan Ponorogo kelas B sebanyak 20 siswa seluruhnya akan dijadikan sebagai subyek penelitian.

Penelitian ini terdiri dari dua buah variabel, yaitu variabel bebas (variabel X) dan variabel terikat (variabel Y). Variabel yang mempengaruhi disebut variabel penyebab, variabel bebas atau independent variable (X) sedangkan variabel akibat disebut variabel tidak bebas, variabel tergantung, variabel terikat atau dependent variable $(\mathrm{Y})^{36}$. Antara variabel bebas dan terikat terdapat hubungan asosiatif, yaitu variabel bebas mempengaruhi variabel terikat. Instrumen pengumpulan data yang digunakan dalam penelitian ini adalah:

Tabel 1

Instrumen Pengumpulan Data

\begin{tabular}{lll}
\hline \multicolumn{1}{c}{ Judul } & \multicolumn{1}{c}{ Variabel } & \multicolumn{1}{c}{ Instrumen } \\
\hline hubungan antara & tingkat & biodata Siswa RA \\
tingkat pendidikan ibu & pendidikan ibu. & Muslimat NU 074 \\
dan kecerdasan & & Ronowijayan \\
logika-matematika & & Ponorogo. \\
Siswa RA Muslimat & & \\
NU 074 Ronowijayan & & \\
Ponorogo & & \\
\hline
\end{tabular}

Teknik pengumpulan adalah prosedur yang sistematik dengan Memperhatikan penggarisan yang telah ditentukan. ${ }^{37}$ Dalam penelitian ini, teknik pengumpulan data yang digunakan adalah dokumentasi. Dokumentasi berasal dari kata "dokumen" yang artinya barang-barang tertulis. ${ }^{38}$ Dokumen adalah catatan yang isinya merupakan pernyataan tertulis yang disusun oleh seseorang

${ }^{35}$ Sugiyono, Metode Penelitian Pendidikan ..., hlm. 124 - 125.

${ }^{36}$ Arikunto, Prosedur Penelitian..., hlm. 119.

37 P. Joko Subagyo, Metode Penelitian dalam Teori dan Praktek (Jakarta: Rineka Cipta, 2004), hlm.38.

${ }^{38}$ Lexy Moleong, Metodologi Penelitian (Jakarta: Rineka Cipta, 2002), hlm. 135 . 
atau lembaga untuk keperluan pengujian suatu peristiwa dan berguna bagi sumber data. ${ }^{39}$ Teknik ini dilakukan untuk memperoleh data non manusia yang berupa data siswa yang menjadi subyek penelitian yaitu tentang tingkat pendidikan ibu dari siswa RA Muslimat NU 074 Ronowijayan Ponorogo dan data mengenai kecerdasan logika-matematika siswa berdasarkan Buku Laporan Perkembangan Siswa RA Muslimat NU 074 Ronowijayan Ponorogo. Selain itu juga dapat diperoleh data mengenai gambaran umum sekolah, sejarah berdirinya sekolah, visi dan misi sekolah, struktur organisasi, keadaan guru dan sebagainya.

Analisis data adalah proses penghimpunan atau pengumpulan, pemodelan dan transformasi data dengan tujuan untuk menyoroti dan memperoleh informasi yang bermanfaat, memberikan saran, kesimpulan dan mendukung pembuat keputusan. ${ }^{40}$ Teknik analisis data digunakan untuk menjawab rumusan masalah dan melakukan penghitungan untuk menguji hipotesis yang telah diajukan.

Rumusan masalah nomor satu dijawab dengan menggunakan rumus persentase, yaitu $P=\frac{f_{i}}{n} \times 100 \%$.

Keterangan:

$P=$ Angka persentase

$f_{i}=$ Frekuensi pada kelas tersebut

$n=$ Jumlah data $^{41}$

Rumusan masalah nomor dua dijawab dengan rumus sebagai berikut:

1. Mencari Mean

$$
=M_{x}=\frac{\sum f X}{n} 42
$$

2. Mencari Standar Deviasi

$$
=S D_{x}=\sqrt{\frac{\sum f x^{2}}{n}}
$$

Keterangan:

$$
M_{x}=\text { Mean rata-rata }
$$

${ }^{39}$ Mahmud, Metode Penelitian Pendidikan (Bandung: Pustaka Setia, 2011), hlm. 168.

${ }^{40}$ Restu Kartiko Widi, Asas Metodologi Penelitian (Yogyakarta, Graha Ilmu, 2010), hlm. 253. 2013), 20.

41 Retno Widyaningrum, Statistika (Yogyakarta: Pustaka Felicha,

${ }^{42}$ Widyaningrum, Statistika, hlm. 54. 


$$
\begin{aligned}
& S D_{x}=\text { Standar deviasi } \\
& \sum f x^{2}=\begin{array}{l}
\text { Jumlah hasil perkalian antara } \\
\text { frekuensi dengan deviasi yang }
\end{array} \\
& \text { sudah dikuadratkan. }{ }^{43}
\end{aligned}
$$

Kemudian rumusan masalah nomor 3 dijawab dengan menggunakan Teknik Korelasi Koefisien Kontingensi (Contingency Coefficient Correlation) atau yang biasa dikenal dengan Koefisien Kontingensi. Teknik ini digunakan karena data yang dikorelasikan dalam penelitian ini berbentuk kategori, yaitu data variabel tingkat pendidikan ibu yang terdiri dari tingkat pendidikan tinggi, sedang dan rendah juga data variabel kecerdasan logikamatematika yang terdiri dari kecerdasan logika-matematika tinggi, sedang dan rendah.

Adapun rumus Koefisien Kontingensi adalah sebagai berikut:

$$
=C=\sqrt{\frac{\chi^{2}}{\chi^{2}+n}}
$$

Nilai $\chi^{2}$ diperoleh dari $\sum \frac{\left(f_{0}-f_{t}\right)^{2}}{f_{t}}$. Nilai $\mathrm{C}$ yang diperoleh kemudian diubah ke dalam Angka Indeks Korelasi Phi dengan rumus:

$$
=\Phi=\frac{C}{\sqrt{1-C^{2}}}
$$

Keterangan:

$C$ : Angka indeks Korelasi Koefisien Kontingensi

$\chi^{2}$ : Angka indeks Chi kuadrat

$n:$ Jumlah data

$f_{b}:$ Frekuensi observasi

$f_{k}:$ Frekuensi teoritik. $^{44}$

\footnotetext{
${ }^{43}$ Widyaningrum, Statistika, hlm. 95.

${ }^{44}$ Widyaningrum, Statistika, hlm. 135.
} 


\section{F. Hasil Penelitian}

1. Tingkat Pendidikan Ibu Siswa RA Muslimat NU 074 Ronowijayan Ponorogo

Tabel 2

Distribusi Frekuensi Relatif Tingkat Pendidikan Ibu

\begin{tabular}{ccc}
\hline Kategori & Frekuensi & P \\
\hline Rendah & 3 & 15 \\
\hline Sedang & 7 & 35 \\
\hline Tinggi & 10 & 50 \\
\hline Jumlah & 20 & 100 \\
\hline
\end{tabular}

Dari hasil penghitungan di atas diketahui tingkat pendidikan ibu yang termasuk kategori rendah sebanyak 3 orang atau $15 \%$, kategori sedang sebanyak 7 orang atau $35 \%$ dan kategori tinggi sebanyak 10 orang atau $50 \%$.

2. Kecerdasan Logika-Matematika Siswa RA Muslimat NU 074 Ponorogo

Tabel 3

Pengkategorian Variabel

Kecerdasan Logika-Matematika

\begin{tabular}{cccc}
\hline No. & Skor & Kategori & Frekuensi \\
\hline 1. & $>62,103$ & Tinggi & 3 \\
\hline 2. & $44,697-62,1103$ & Sedang & 13 \\
\hline 3. & $<44,697$ & Rendah & 4 \\
\hline & & Jumlah & 20 \\
\hline
\end{tabular}

Dari hasil penghitungan di atas diketahui kecerdasan logika-matematika yang termasuk kategori rendah sebanyak 3 orang, kategori sedang sebanyak 13 orang dan kategori tinggi sebanyak 4 orang atau 50\%.

3. Hubungan antara Tingkat Pendidikan Ibu dan Kecerdasan Logika-Matematika Siswa RA Muslimat NU 074 Ponorogo Data untuk menghitung besarnya Koefisien Kontingensi dapat dilihat pada tabel berikut: 
Tabel 4

Data Tingkat Pendidikan Ibu

dan Kecerdasan Logika-Matematika

\begin{tabular}{|c|c|c|c|c|c|}
\hline & & \multicolumn{3}{|c|}{ Tingkat Pendidikan Ibu } & \multirow[t]{2}{*}{ Jumlah } \\
\hline & & Tinggi & Sedang & Rendah & \\
\hline \multirow{3}{*}{$\begin{array}{l}\text { Kecerdasan } \\
\text { Logika- } \\
\text { Matematika }\end{array}$} & Tinggi & 3 & 0 & 0 & 3 \\
\hline & Sedang & 7 & 4 & 2 & 13 \\
\hline & Rendah & 0 & 3 & 1 & 4 \\
\hline \multicolumn{2}{|c|}{ Jumlah } & 10 & 7 & 3 & 20 \\
\hline
\end{tabular}

Berdasarkan data di atas dapat dihitung Koefisien Kontingensi antara tingkat pendidikan ibu dan kecerdasan logika-matematika sebagai berikut:

\section{Tabel 5}

Penghitungan Koefisien Kontingensi antara Tingkat Pendidikan Ibu dan Kecerdasan Logika-Matematika

\begin{tabular}{cccccc}
\hline \multicolumn{1}{l}{ Sel } & & & & & $\left(f_{0}-f_{t}\right)^{2}$ \\
\hline 1 & $f_{0}$ & $f_{t}$ & $f_{0}-f_{t}$ & $\left(f_{0}-f_{t}\right)^{2}$ & $f_{t}$ \\
\hline 2 & 3 & 1,5 & 1,5 & 2,25 & 1,5 \\
\hline 3 & 0 & 1,05 & $-1,05$ & 1,1025 & 1,05 \\
\hline 4 & 0 & 0,45 & $-0,45$ & 0,2025 & 0,45 \\
\hline 5 & 4 & 6,5 & 0,5 & 0,25 & 0,038462 \\
\hline 6 & 2 & 4,55 & $-0,55$ & 0,3025 & 0,066484 \\
\hline 7 & 0 & 2 & -2 & 4 & 0,001282 \\
\hline 8 & 3 & 1,4 & 1,6 & 2,56 & 1,828571 \\
\hline 9 & 1 & 0,6 & 0,4 & 0,16 & 0,266667 \\
\hline Jumlah & 20 & 20 & 0 & 10,83 & 7,201465 \\
\hline
\end{tabular}

Berdasarkan data tersebut diperoleh $\chi^{2}=\sum \frac{\left(f_{0}-f_{t}\right)^{2}}{f_{t}}=$ 7,201465. Kemudian nilai tersebut dimasukkan ke dalam rumus Koefisien Kontingensi sebagai berikut:

$$
\begin{aligned}
=C & =\sqrt{\frac{\chi^{2}}{\chi^{2}+n}}=\sqrt{\frac{7,201465}{7,201465+20}}=\sqrt{\frac{7,201465}{27,201465}}=\sqrt{0,264745} \\
& =0,514534
\end{aligned}
$$


Nilai C yang diperoleh kemudian diubah ke dalam Angka Indeks Korelasi Phi dengan rumus:

$$
\begin{gathered}
=\Phi=\frac{C}{\sqrt{1-C^{2}}}=\frac{0,514534}{\sqrt{1-0,514534^{2}}}=\frac{0,514534}{\sqrt{1-0,264745}}=\frac{0,514534}{\sqrt{0,735255}}= \\
\frac{0,514534}{0,85747}=0,6000606
\end{gathered}
$$

\section{G. Pembahasan dan Interpretasi}

Berdasarkan penghitungan Koefisien Kontingensi antara tingkat pendidikan ibu dan kecerdasan logika-matematika siswa RA Muslimat NU 074 Ponorogo diperoleh $\Phi_{0}=0,6000606$. Berarti tingkat pendidikan ibu memberikan kontribusi terhadap kecerdasan logika-matematika sebesar 60,00606 \% dan sisanya sebesar 39,99394\% ditentukan oleh faktor lain.

Berdasarkan penghitungan Koefisien Kontingensi antara tingkat pendidikan ibu dan kecerdasan logika-matematika diperoleh $\Phi_{0}=0,6000606$. Kemudian mencari nilai $d b=n-$ $n r=20-2=18$, selanjutnya dikonsultasikan dengan Tabel Nilai "r" Product Moment pada taraf signifikansi 5\% diperoleh $\Phi_{\text {tabel }}=0,444$. Kriteria pengujian $\Phi_{0}>\Phi_{\text {tabel }}$ maka $H_{0}$ ditolak dan $H_{a}$ diterima artinya signifikan. Ternyata $\Phi_{0}>\Phi_{\text {tabel }}$ atau $\Phi_{0}$ $>\Phi_{\text {tabel }}$ atau 0,6000606 >0,444 maka $\mathrm{H}_{0}$ ditolak dan $\mathrm{H}_{\mathrm{a}}$ diterima. Berarti ada hubungan yang positif dan signifikan antara tingkat pendidikan ibu dan kecerdasan logikamatematika siswa RA Muslimat NU 074 Ronowijayan Ponorogo.

\section{H. Penutup}

Hasil penelitian ini menunjukan bahwa:

1. Tingkat pendidikan ibu siswa RA Muslimat NU 074 Ronowijayan Ponorogo yang termasuk kategori tinggi sebanyak 10 orang atau 50\%, kategori sedang sebanyak 7 orang atau $35 \%$ dan kategori rendah sebanyak 3 orang atau $15 \%$.

2. Kecerdasan logika-matematika siswa RA Muslimat NU 074 Ronowijayan Ponorogo yang termasuk kategori tinggi dengan skor > 62,103 sebanyak 3 orang, kategori sedang dengan skor 44,697 - 62,103 sebanyak 13 orang dan kategori rendah dengan skor $<44,697$ sebanyak 4 orang. 
3. Terdapat hubungan yang positif dan signifikan antara tingkat pendidikan ibu dan kecerdasan logika-matematika siswa RA Muslimat NU 074 Ronowijayan Ponorogo pada taraf signifikansi 5\% dengan $\boldsymbol{\Phi}_{0}>\Phi_{\text {tabel }}$ atau 0,6000606 $>0,444$ maka $\mathrm{H}_{0}$ ditolak dan $\mathrm{H}_{\mathrm{a}}$ diterima.

\section{Kepustakaan}

Arikunto, Suharsimi, Prosedur Penelitian: Suatu Pendekatan Praktek, Jakarta: Rineka Cipta, Azwar, Saifudin, Pengantar Psikologi Inteligensi, Yogyakarta: Pustaka Pelajar, 2006.

Budiningsih, C. Asri, Belajar dan Pembelajaran, Jakarta: Rineka Cipta, 2005.

Crain, William, Teori Perkembangan: Konsep dan Aplikasi, Terj. Yudi Santoso, Yogyakarta: Pustaka Pelajar, 2007.

Efendi, Agus, Revolusi Kecerdasan Abad 21: Kritik MI, EI, SQ, $A Q$ \& Successful Intelligence atas IQ, Bandung: Alfabeta, 2005.

Endarmoko, Eko, Tesaurus Bahasa Indonesia, Jakarta: Gramedia Pustaka Utama, 2009.

Gardner, Howard, Kecerdasan Majemuk (Multiple Intelligences)

Teori dalam Praktek, Terj. Alexander Sindoro, Batam: Interaksara, 2003.

Idi, Abdullah \& Safarina H. D, Sosiologi Pendidikan Individu, Masyarakat dan Pendidikan, Jakarta: Rajawali, 2011.

Mahmud, Metode Penelitian Pendidikan, Bandung : Pustaka Setia, 2011.

Moleong, Lexy, Metodologi Penelitian, Jakarta : Rineka Cipta, 2002.

Musrofi, M, Melesatkan Prestasi Akademik Siswa: Cara Praktis Meningkatkan Prestasi Akademik Siswa Tanpa Kekerasan dan Tanpa Harus Menambah Jam Belajar, Yogyakarta : Pedagogia, 2010.

Papalia, Diane E., Human Development (Psikologi Perkembangan) Edisi Kesembilan, Terj. A. K. Anwar, Jakarta: Kencana Prenada Media Group, 2008. 
Saifullah, Mencerdaskan Anak: Mengoptimalkan Kecerdasan Intelektual, Emosi dan Spiritual Anak, Jombang: Lintas Media, 2004.

Santrock, John W., Perkembangan Anak Jilid 1, Edisi Kesebelas, Terj. Mila Rachmawati \& Anna Kuswanti, Jakarta: Erlangga, 2007.

Slameto, Belajar dan Faktor-faktor yang Mempengaruhinya, Jakarta: Rineka Cipta, 2003.

Stenberg, Robert J. Psikologi Kognitif ,Terj. Yudi Santoso. Yogyakarta: Pustaka Pelajar, 2008.

Subagyo, P. Joko, Metode Penelitian dalam Teori dan Praktek, Jakarta: Rineka Cipta, 2004.

Sugiyono, Metode Penelitian Pendidikan: Pendekatan Kuantitatif, Kualitatif dan $R$ \& D, Bandung : Alfabeta. 2006.

-----, Statistika untuk Penelitian, Bandung: Alfabeta, 2009.

Suharsono, Melejitkan IQ, IE \& IS, Depok: Inisiasi Press, 2004.

Sukmadinata, Nana Syaodih, Metode Penelitian Pendidikan, Bandung: Remaja Rosdakarya, 2007.

Tim Guru RA Muslimat NU 074 Ronowijayan Siman Ponorogo. Kurikulum Tingkat Satuan Pendidikan (KTSP) RA Muslimat NU 074 Ronowijayan Siman Ponorogo Tahun Pelajaran 2012/2013, Ponorogo, 2012.

Tim Penyusun Kamus Pusat Bahasa Edisi 3, Kamus Besar Bahasa Indonesia, Jakarta: Balai Pustaka, 2005.

Undang-Undang Republik Indonesia Nomor 20 Tahun 2003 tentang Sistem Pendidikan Nasional.

Uno, Hamzah B. \& Masri Kuadrat, Mengelola Kecerdasan dalam Pembelajaran: Sebuah Konsep Pembelajaran Berbasis Kecerdasan, Jakarta: Bumi Aksara, 2009.

Widi, Restu Kartiko, Asas Metodologi Penelitian, Yogyakarta : Graha Ilmu, 2010.

Widyaningrum, Retno, Statistika Edisi Revisi, Yogyakarta: Pustaka Felicha, 2013. 
